\title{
«ОНЛАЙН-КОЛО»: ДОСВІД ПСИХОЛОГІЧНОЇ ПІДТРИМКИ І ДОПОМОГИ НАСЕЛЕННЮ ПІД ЧАС ПАНДЕМІї COVID-19
}

https://doi.org/10.37472/2707-305X-2020-2-1-7-8

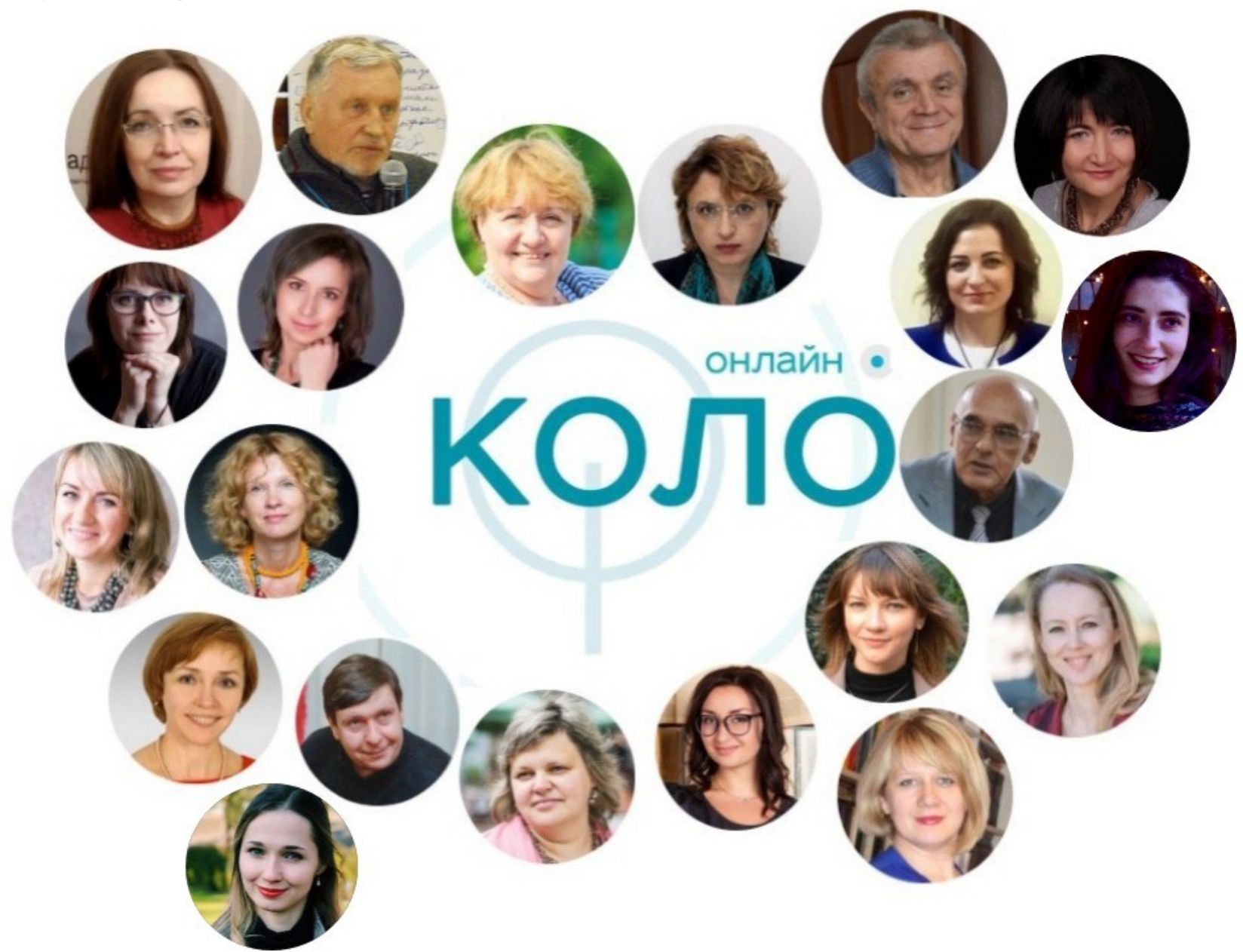

\section{СЛЮСАРЕВСЬКИЙ}

Микола Миколайович

член-кореспондент НАПН

України, директор Iнституту

сочіальної та політичної

психології Начіональної

академії педагогічних наук

України, віцепрезидент

Товариства психологів

України, м. Київ, Україна

(iD)
Анотація. На базі Навчально-практичного чентру психологічних інновацій Інституту соціальної та політичної психології НАПН України створено Відкритий проєкт психологічної підтримки і допомоги населенню під час пандемії COVID-19 "ОНЛАЙН-КОЛО», який постійно працює з 25 березня 2020 р. Проєкт спрямовано на збереження психологічного здоров'я та благополуччя громадян, поширення науково обгрунтованої, достовірної і корисної інформації, рекомендацій і методик з професійної допомоги та самодопомоги під час пандемії. Окремим напрямом проєкту є підтримка фрахівців соціального профрілю (психологів, педагогів, соціальних працівників) і психологів системи освіти у вигляді методичного забезпечення роботи з населенням під час пандемії та профрілактики емоційного вигоряння. Заходами проєкту охоплено вже понад 25000 осіб.

Ключові слова: психологічна допомога; пандемія; волонтерський проєкт; COVID-19; психологічне благополуччя.

Наукові працівники Інституту соціальної та політичної психології Національної академії педагогічних наук України мають значний 
досвід організації психологічної допомоги населенню під час кризових і надзвичайних ситуацій - Революції Гідності, російсько-української війни, гібридної агресії у медійному просторі. Загроза розповсюдження коронавірусу, яка зумовлює досить жорсткі запобіжні заходи, безумовно, $€$ черговим викликом для нашого суспільства, на який академічні психологи - і відомі вчені, і досвідчені практики - не можуть не відреагувати. 25 березня ц.р. на базі Навчально-практичного центру психологічних інновацій Інституту соціальної та політичної психології НАПН України стартував Відкритий проєкт психологічної підтримки і допомоги населенню під час пандемії COVID-19 «ОНЛАЙН-КОЛО».

Проєкт від самого початку був спрямований на збереження психологічного здоров'я і благополуччя громадян під час епідемії. Замислюючи нове волонтерство, команда проєкту прагнула поширювати науково обгрунтовану, достовірну і корисну інформацію, яка могла б допомогти громадянам опанувати неприємні емоційні стани, ефективно побудувати свій графік у разі переходу на віддалений режим роботи, підтримувати інтелектуальний і фізичний тонус та успішно розвивати стосунки з близькими в умовах самоізоляції та соціального дистанціювання.

Окремим напрямом проєкту стала підтримка фахівців соціального профілю (психологів, педагогів, соціальних працівників) щодо підвищення кваліфікаційного рівня у сфері кризового консультування, методичного забезпечення роботи 3 населенням під час пандемії, профілактики емоційного вигоряння.

Зокрема, для психологів системи освіти, які наразі фактично виконують функції менеджерів 3 психологічного здоров'я у колективах закладів освіти і почасти - в територіальних громадах, що утримують ці заклади, передбачено кілька напрямів психологічної підтримки:

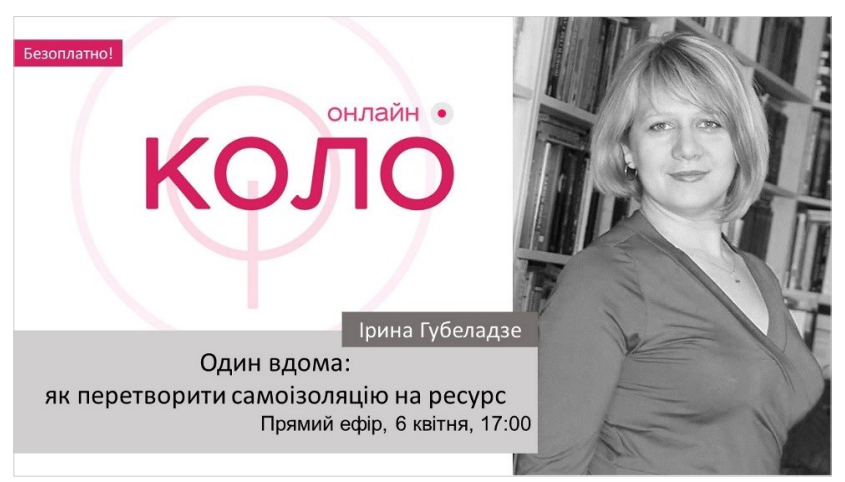

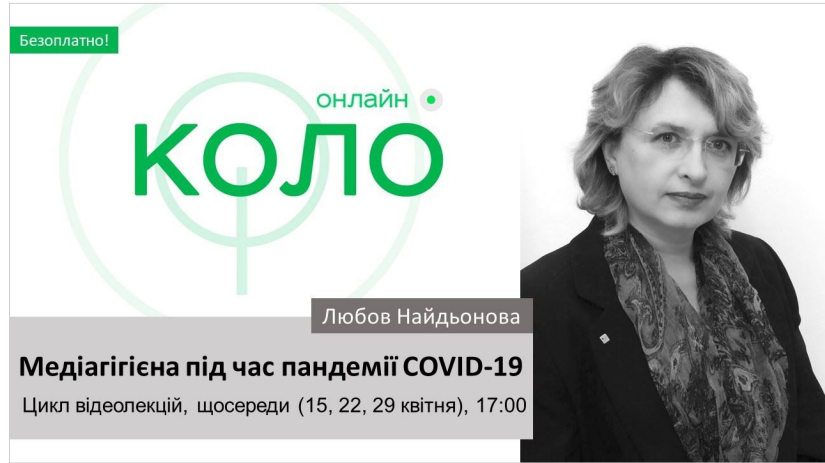

- тематичні вебінари та майстер-класи 3 методик психологічної допомоги населенню в умовах кризи та надзвичайних ситуацій;

- супервізії складних випадків і ситуацій у роботі психолога системи освіти;

- групи підтримки з метою профілактики емоційного вигорання;

- індивідуальні консультації за запитом;

- розробка та поширення науковопопулярного контенту (інфографіки, відеоролики, текстові матеріали) із рекомендаціями щодо зменшення ризиків (емоційних, інформаційних, поведінкових, особистісних і міжособистісних) під час пандемії.

Усі ці інформаційні продукти та матеріали викладають у вільному доступі для широкого загалу, щоб задовольнити потребу в актуальній, достовірній, релевантній і корисній інформації не тільки психологів системи освіти та інших учасни ків освітнього процесу, а й решти громадян.

Від початку проєкту відбулося 20 відеосемінарів за різною тематикою - від опанування негативних емоційних станів у дітей і дорослих до самовизначення особистості в кризових умовах:

- Карантин: як зберегти здоровий глузд, ведуча - Ольга Плетка (25 березня 2020 р.);

- Поки всі дома: як пережити карантин і не пересваритися, Ірина Губеладзе (26 березня 2020 р.);

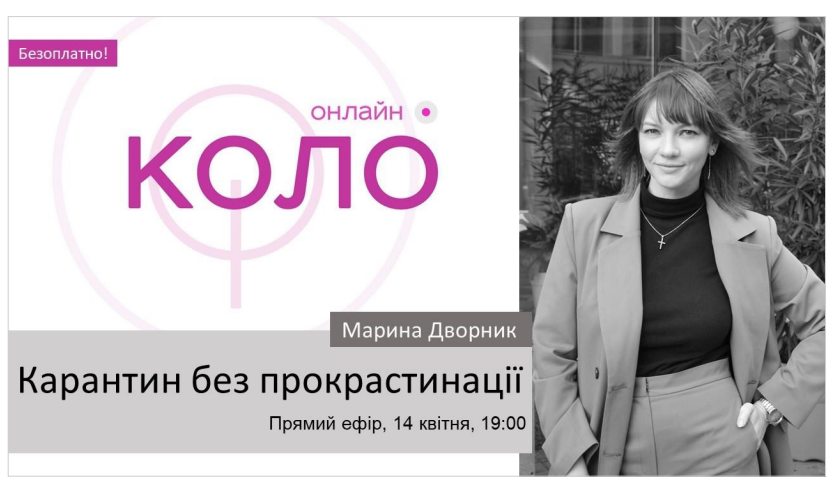




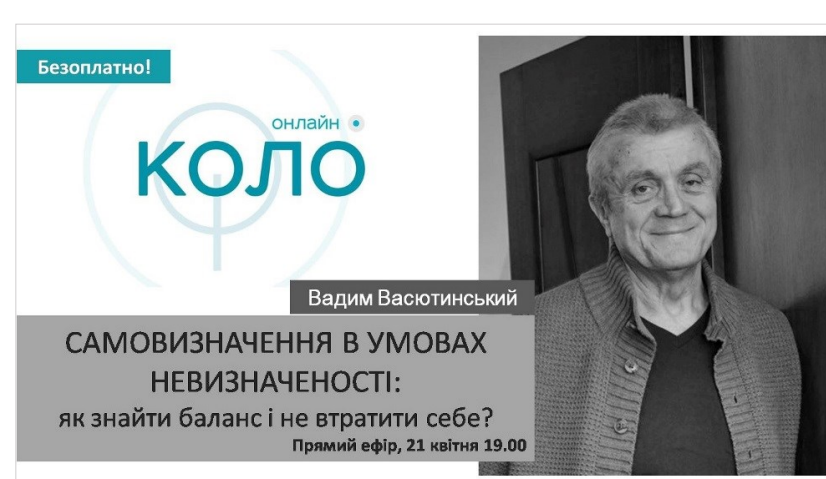

- Страх захворіти: способи примирення, Катерина Мирончак (29 березня 2020 р.);

- Самодопомога при негативних емоційних станах, Борис Лазоренко (31 березня 2020 р.);

- Гумор як ресурс при пандемії, Марина Дворник (1 квітня 2020 р.);

- Батькам: як допомогти дитині опанувати емоції, за мотивами книги «Монстрик та його кольори», Марічка Бурдукало (2 квітня 2020 р.);

- Батькам: методи зниження тривожності дитини на карантині, Анастасія Голота (3 квітня 2020 р.);

- Медитації люблячої доброти, Юлія Гундертайло (5 квітня 2020 р.);

- Один вдома: як перетворити самоізоляцію на ресурс, Ірина Губеладзе (6 квітня 2020 р.);

- Звідки брати сили на карантині: модель BASIC Ph, Юлія Гундертайло (8 квітня 2020 р.);

- Жуйка для мозку: як позбутись нав'язливих неприємних думок, Ольга Кухарук (9 квітня 2020 р.);

- Карантин без прокрастинації, Марина Дворник (14 квітня 2020 р.);

- Пережити карантин: ресурс гніву, Ольга Плетка (16 квітня 2020 р.);

- Самовизначення в умовах невизначеності: як знайти баланс і не втратити себе?, Вадим Васютинський (21 квітня 2020 р.);

- Медіагігієна під час пандемії Covid-19. Цикл відеолекцій, Любов Найдьонова (15, 22, 29 квітня 2020 р.);

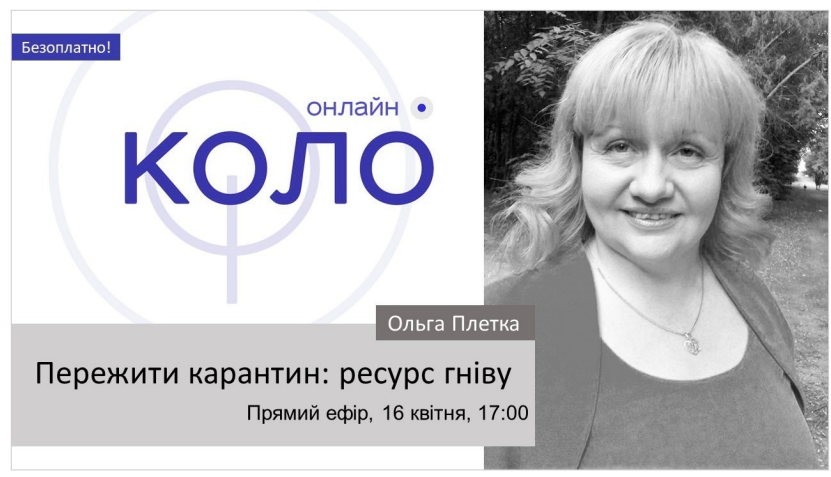

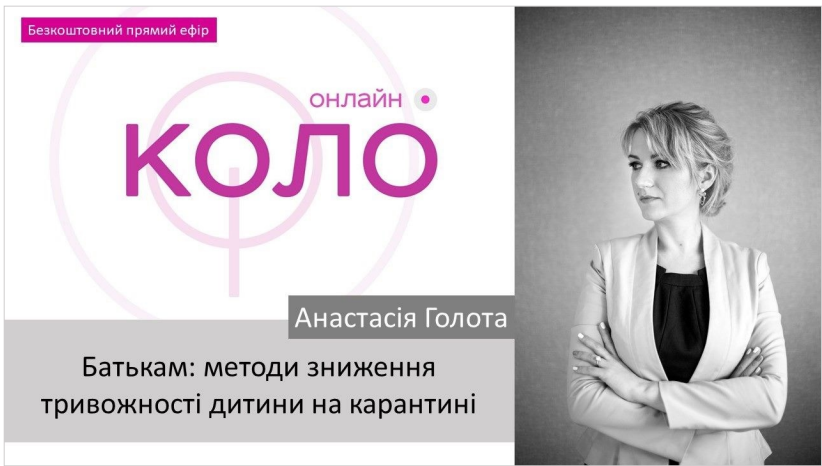

- Підліток на Карантині: як вгамувати Дракона чи розтормошити Лінивця, Ірина Губеладзе (6 травня 2020 р.).

Ці події відвідало понад 25 тис. осіб. Близько 100 осіб звернулися із запитом на допомогу у форматі індивідуальної консультації / супервізії або групової роботи. Варто зазначити, що регулярну супервізійну та психологічну підтримку отримують і самі фахівці, задіяні в проєкті як волонтери. Звісно, вся допомога надається дистанційно та на безоплатній основі.

Кілька слів про команду проєкту. Наразі проєкт реалізують 22 психологи-науковці, які мають багаторічний досвід дослідницької, педагогічної та терапевтичної роботи, належать до різних психотерапевтичних шкіл - від гештальтпідходу до сімейства арттерапевтичних практик, але однаковою мірою спираються на доказов методи, науковий аналіз ефективності теорій практик, результати власних емпіричних досліджень, проведених в Україні. Особливо приємно підкреслити, що поруч із такими високопрофесійними фахівцями, як Любов Найдьонова, Вадим Васютинський, Борис Лазоренко у проєкті працюють перспективні молоді вчені, докторанти та аспіранти Інституту - Ірина Губеладзе, Марина Дворник, Катерина Мирончак, Анастасія Голота, Марічка Бурдукало, Валерія Діброва, Ірина Нестеренко. Не можна оминути увагою активну позицію керівника Навчально-практичного центру психологічних інновацій Наталії Умеренкової, з подачі якої проєкт, власне, й почався, а також Ольги Плетки, Олени Вознесенської, Ольги Кухарук, Юлії Гундертайло, Оксани Скнар, Володимира Савінова - постійних учасників усіх волонтерських ініціатив Інституту. Активно включилися у проєкт і стали важливими учасниками команди нові співробітники Інституту - Світлана Поліщук, Людмила Гриценок, Світлана Чуніхіна.

Безумовно, досвід реалізації такого проєкту, який корегується майже щодня, ураховуючи мінливий і непередбачуваний розвиток самої 


\section{КОЛО \\ ГРУПА ПСИХОЛОГІЧНОї ПІДТРИМКИ для фрахівців}

пандемії, потребуватиме глибокого осмислення тоді, коли ситуація стане більш прогнозованою, а гострота реакцій на неї піде на спад.

Водночас уже зараз впевнено можна стверджувати, що оперативність реакції психологічної спільноти на масштабні суспільні виклики на кшталт пандемії $\epsilon$ важливішою за теоретичну презентабельність такої реакції. Адже непередбачуваність, невизначеність і невідворотність криз, схоже, буде постійним супутником нашого повсякденного життя.

\section{СПИСОК ВИКОРИСТАНИХ ДЖЕРЕЛ}

Бурдукало, М. (2020, 2 квітня). Батькам: як допомогти дитині опанувати емоції, за мотивами книги «Монстрик та його кольори» [Відео]. Facebook. https://www.facebook.com/centerispp/ videos/3593560420718092/

Васютинський, В. (2020, 21 квітня). Самовизначення в умовах невизначеності: як знайти баланс і не вmратити себе? [Відео]. Facebook. https:// www.facebook.com/SpilnotalSPP/ videos/262615101803397/

Голота, А. (2020, 3 квітня). Батькам: методи зниження тривожності дитини на карантині [Відео]. Facebook. https://www.facebook.com/centerispp/ videos/575028416703011/

Група психологічної підтримки для населення. (2020). [Подія]. Facebook. https://www.facebook.com/ events/886631841772735/

Губеладзе, І. (2020а, 26 березня). Поки всі дома: як пережити карантин і не пересваритися [Відео]. Facebook. https://www.facebook.com/centerispp/ videos/261304808220568/

Губеладзе, І. (2020b, 6 квітня). Один вдома: як перетворити самоізоляцію на ресурс [Відео]. Facebook. https://www.facebook.com/centerispp/ videos/712554786155359/

Губеладзе, І. (2020с, 8 квітня). Ізолячія на самоті: правила самодопомоги [Інфографіка]. Facebook. https://www.facebook.com/centerispp/ posts/532202247487767/

Губеладзе, І. (2020d, 6 травня). Підліток на Карантині: як вгамувати Дракона чи розтормошити Лінивия [Відео]. Facebook. https:// www.facebook.com/events/296854301310401/
Губеладзе, І. (2020е, 8 травня). Як не nompanumu на гачок дофаміну при стресі [Інфографіка]. Facebook. https://www.facebook.com/centerispp/ posts/549925022382156/

Гундертайло, Ю. (2020а, 5 квітня). Медитації люблячої доброти [Відео]. Facebook. https:// www.facebook.com/events/212962126686486/

Гундертайло, Ю. (2020b, 8 квітня). Звідки брати сили на карантині: модель ВАSIC Ph [Відео]. Facebook. https://www.facebook.com/events/275622703445041/

Гундертайло, Ю. (2020с, 15 квітня). Звідки брати сили на карантині: модель BASIC Ph [Інфографіка]. Facebook. https://www.facebook.com/centerispp/ posts/536657877042204/

Дворник, М. (2020а, 1 квітня). Гумор як ресурс при пандемії [Відео]. Facebook. https://www.facebook.com/ centerispp/videos/845038669295442/

Дворник, М. (2020b, 14 квітня). Карантин без прокрастинаціi [Відео]. Facebook. https:// www.facebook.com/events/534769467451304/

Дворник, М. (2020b, 16 квітня). Карантин без прокрастинації [Інфографіка]. Facebook. https:// www.facebook.com/centerispp/posts/537049203669738

Індивідуальні консультації (запис) \#онлайн_коло. (2020). [Google Form]. https://bit.ly/2WVedC1

Кухарук, О. (2020, 9 квітня). Жуйка для мозку: як позбутись нав'язливих неприємних думок [Відео]. Facebook. https://www.facebook.com/events/ 495770011308621/

Лазоренко, Б. (2020, 31 березня). Самодопомога при негативних емоційних станах [Відео]. Facebook. https://www.facebook.com/centerispp/ videos/212139913441124/

Мирончак, К. (2020, 29 березня). Страх захворіти: способи примирення [Відео]. YouTube. https:// youtu.be/_likTZCc83Y

Навчально-практичний центр психологічних інновацій ІСПП НАПН України. (n.d.). Головна [Facebook Page]. Facebook. https://www.facebook.com/centerispp/

Навчально-практичний центр психологічних інновацій ІСПП НАПН України. (2020, 1 квітня). Вебінари і майстер-класи психологічної самодопомоги під час карантину (ОНОВЛЮЄТЬСЯ). Facebook. https:// www.facebook.com/centerispp/posts/528555037852488

Найдьонова, Л. (2020, 15-29 квітня). Медіагігієна під час пандемії Covid-19 : цикл лекцій [Відео]. Facebook. https://www.facebook.com/events/263259258172869/

Плетка, О. (2020а, 25 березня). Карантин: як зберегmи здоровий глузд [Відео]. Facebook. https:// www.facebook.com/centerispp/videos/2471594966487422/

Плетка, О. (2020b, 16 квітня). Пережити карантин: ресурс гніву [Відео]. Facebook. https:// www.facebook.com/events/2617491658507020/

Плетка, О. (2020с, 28 квітня). Що варто знати про гнів під час пандемії [Інфографіка]. Facebook. https:// www.facebook.com/centerispp/posts/544416979599627

Реєстрація для участі в інтервізійній онлайн-групі для фрахівців системи освіти (шкільних, дошкільних психологів, соціальних педагогів, вчителів, mомо). (2020). [Google Form]. https://bit.ly/2T3uZxD 


\section{“ONLINE-KOLO": THE EXPERIENCE OF PSYCHOLOGICAL SUPPORT AND ASSISTANCE TO THE POPULATION DURING THE COVID-19}

Mykola Slyusarevskyy

PhD in Psychology, Corresponding Member of NAES of Ukraine, Director, Institute for Social and Political Psychology of the National Academy of Educational Sciences of Ukraine, Vice-president, The Society of Psychologists of Ukraine, Kyiv, Ukraine

Abstract. Open Project for psychological support and assistance to the population during the COVID-19 "ONLINEKOLO" pandemic was created on the basis of the Educational and Practical Centre of Psychological Innovation of the Institute for Social and Political Psychology of the National Academy of Educational Sciences of Ukraine. The project is aimed at preserving of psychological health and well-being of the citizens. It works on spreading scientifically reliable and useful information, recommendations, and techniques for professional assistance and self-help during a pandemic. Another part of the project is providing support for the social help specialists (psychologists, educators, social workers). The psychologists of the education system are getting methodological support for work with the population during the pandemic and for the prevention of emotional burnout. The audience of more than 25,000 people has been covered during this project.

Keywords: psychological help; pandemic; volunteer project; COVID-19; psychological well-being.

Дата публікації: 14 травня 2020 р. 